\title{
Analysis on Economic Situation and Marketing Strategies of New Oriental Education
}

\begin{abstract}
Zhengyu Bao
Qingdao No.2 Middle School, Qingdao 266000, China

*Corresponding author. Email: bariumoxide@outlook.com

ABSTRACT

At present, China has a large demand for education industry, with all kinds of education institutions on the market emerging in endlessly. Training that focuses on English training industry ushered in the explosive growth over the past years. New Oriental Education has advantages in the competition with its old brand influence and advertisements done by stars that raise its popularity. Strategies on courses and management explain its advantage academically. This paper takes New Oriental education technology group as the research object, combined with the trend of the development of whole industry, and analyzes its key marketing strategies and commercial situations. Existing problems and predictions are also included in the paper, such as disadvantages caused by its initial nature and possible improvements to the company. The research and analysis of New Oriental's market strategy has certain value for other company taking as reference. In addition, the author's research also proposes some solutions to the existing problems to a certain extent. The relevant research of New Oriental Education has promoted the sustainable development of China's education industry.
\end{abstract}

Keywords: Marketing, Education company, Epidemic influence, Structural adjustment

\section{INTRODUCTION}

In the $21^{\text {st }}$ century, with expanding population and fierce competition, more parents are aware of the importance of education. Thus, more of them started to purchase various extracurricular classes, such as courses to practice math or languages or other interests for their children. As a high school student, the author was also a student of New Oriental Education and has always been paying attention to its marketing situations. Through researching on the internet and first-hand observation, the author found changes happening gradually in this large company, including changes from details in class content to overall adjustment of marketing aims. Some of these changes led the company to continue flourishing over decades, while some delayed in adjustment and caused the loss of students. The paper will discuss both of them, from how its advantages creates its long-lasting lead in the industry, to its existing problems, and some possible solution will be provided.

Among the competition of education companies, as one of top ten Chinese education companies, New Oriental Education performs well from abroad studies to science subjects. It started as a foreign language learning school, and now it has become a company with experience for teaching English, Spanish, French, German and other languages for abroad preparation. With many subsidiary corporations, New Oriental Education is allowed to cover education fields from pre-school education to fundamental education in senior high school. Until May 2014, New Oriental had set up 56 schools, 31 bookstores and 703 learning centers in 50 cities across China. Since its establishment, New Oriental has been teaching students face to face for more than 20 million times [1]. Its high reputation and abundant experience have attracted millions of parents and students to purchase its courses and joins its classes. Even in the situation of epidemic spreading, New Oriental Education still achieved a $15.6 \%$ income increase in the 2020 financial year, with its total student increasing by $26.3 \%$, which is incredible for education companies that need to sacrifice their profits on offline teaching.

Apart from its experience and innovation, marketing strategy also plays a crucial rule in maintaining economic growth of New Oriental Education. As an industry leader, New Oriental has both financial foundation and marketing methods to advertise its 
projects, retain its old customers and attract potential customers. The research on the topic is practical and is done in a qualitative way. This paper will first analyze the marketing situation of New Oriental Education from the perspectives of objective external factors. Then some particular marketing strategies will be analyzed and potential problems will be posed. Advancement of the future will be raised as well.

\section{EXTERNAL FACTORS INFLUENCING MARKETS FOR NEW ORIENTAL EDUCATION}

\subsection{Resource Control in Education Programs Abroad}

It has been more than ten years since China built a mature system for students for studying abroad, and several institutions, including New Oriental Education, were of the pioneers in this industry. With frequent trials and more experience, these forerunners gained reputation and trust from abroad which allowed the company to get more opportunities for itself and its students (clients) before other companies even know about these chances, and when these mutual relationships stabilize, it is even harder for new companies to compete.

\subsection{Influence of Epidemic Situation}

From January 2020, when the COVID-19 virus broke out, China had been dealing with the epidemic by quarantine, which meant that students were not allowed to leave home for extracurricular classes anymore. Thus, a series of offline classes were forced to shut down and online classes were quickly developed and became the mainstream of education method, and in this case, prominent profiting strategy.

\section{ANALYSIS ON MARKETING STRATEGIES AND POTENTIAL PROBLEMS}

\subsection{Analysis on marketing strategies of New Oriental Education}

\subsubsection{Adhesion -one-package service}

By scanning over the web page of New Oriental Education, it is easy to find that there are courses from kindergarten education to university extracurricular courses. The one-package service has always been a specialty of New Oriental Education, and quite a lot of students tend to learn in this institution from a young age all the way when they grow up. For abroad education, the Study Abroad Express program successfully sent thousands of students to their dream school, and they did this by designing personal preparation plans for each student in the program which involves all service for abroad preparation including activity design and essay writing apart from regular language and exam classes [2].

Interviews and survey do prove that one-package service successfully increases the adhesion of its clients with convenient service in both domestic education and abroad education, which makes clients do not need to struggle between other programs after a session of learning. What is more, the uniform education systems save the energy and time of students to get used to new systems of learning if they possibly change other institutions.

\subsubsection{Advantages of a near monopoly situation}

New Oriental Education takes control of some key resources and opportunities that other companies can hardly gain. Additionally, the excellent teacher team of New Oriental Education has summarized a set of advanced exam preparation strategy system, which is still for internal use only. The company has set up hundreds of branches spreading all over China, which successfully wins it economies of scale that decreases its cost when providing extra service, such as its own press which publishes many vocabulary books that are used by students in and out of the institution, while the new starters need to suffer from the increase of cost and the insufficiency of resources. The cooperation with other big companies also helps to increase its positive externalities and expands its reputation. This situation helps New Oriental Education to keep its leading position in the education industry and even accelerate in the pace of development.

\subsubsection{Old brand influence and celebrity advertising effects}

For the old brand influence, since New Oriental Education has always been an experienced forerunner in the education industry that sent so many students to their dream schools, parents and students tend to have a positive impression on the company and its projects and may tend to choose New Oriental Education when they decided to have extracurricular classes. As the company flourished over two decades, its teaching skills and reputation can be guaranteed, and previous successful cases give parents more confidence to believe that their children can also be successful studying in this institution.

In addition, New Oriental Education has been advertised with stars and students from famous universities for a long time. The advertisement successfully attracts more attention of various groups of people which increases the frequency of the company being heard from different people. Star advertisement 
also send out a message that the company has enough money to hire stars, which indirectly assures parents that the company has enough financial support to maintain the quality of its service. According to Yu Minhong, the founder of New Oriental Education, a successful advertisement can lead to "a $80 \%$, and even an $100 \%$ increase in a single year" for some of the branch schools [6].

\subsubsection{Particular strategies on course and price}

New Oriental Education developed different classes for students with different language proficiency and various demand in different phases. It also creates courses for different times such as full-time courses during summer and winter holidays, and even annual classes for National holidays. With its multi-variant courses and extra classes, New Oriental Education now develops various classes for school subjects for students in primary and junior high schools, and opens interview construction classes and abroad planning service, following the trend of international development. The course designs are mature enough to satisfy most needs of students, and thus gathers a wide range of students and potential customers.

The cost structure of the training industry is very complex, so the language training industry more adopts industry competitive pricing and demand-oriented pricing. The language training industry is characterized by low entry threshold and serious homogeneity of courses. In most cases, price is determined by competition. As the courses in the training market are similar, consumers pay more attention to the brand, quality and teaching characteristics of language training institutions. Given that the brand of New Oriental Education Group enjoys a good reputation in the training industry as it provides high teaching quality, it has various strategies for pricing. In terms of pricing, the competition-oriented pricing method and demand-oriented pricing method are often adopted according to the intensity of course competition and market demand of different training programs [3].

\subsection{Existing Problems}

\subsubsection{Negative influence of epidemic situation}

One of the big problems that New Oriental Education is that the popularity of its online classes are not as huge as other main education companies, and the online system is not so mature as well. The author takes Xueersi under TAL Education Group, another main education company in China as an example. Xueersi always advertises its offline classes with its online website, so the online studying platform of Xueersi gains as much reputation, while New Oriental Education seldomly advertises for its own.
Another advantage of Xueersi is that the online classes are developed independently when starting offline classes, while New Oriental education started online classes only a few years ago as an assistance of online classes. It is obvious that Xueersi has already accumulated enough online experience and has a mature online teaching system while New Oriental Education began their online classes for a complement of offline classes, and only started to study for independent online courses for less than a decade.

\subsubsection{Competition between big companies and flourishment of smaller companies}

Competitions rise between big companies, and it is no longer the world for New Oriental Education as ten years ago. Big Old-brand companies like TAL Education Group has taken a large portion on domestic education with solid foundation, and new companies such as New Channel and Woodpecker Education quickly overwhelm the market of abroad education, with quite a few newly-started small companies filling up the gaps. Big companies are reaching economics of scales and gaining more unique resources, and small companies has outstanding mobility, so it is hard for New Oriental Education to keep its lead.

New Oriental Education's large scale give it advantage in diminishing marginal costs, but it also leads to disadvantages related to adjustments for the whole company. With complicated manage systems and various cooperative relationships, making some small adjustments can be long-lasting with the careful examinations of managers and conveyance and conductance of orders of changes. In a particular research about VIE models related to stock ownership [4], which analyzes the problems New Oriental Education in management strata, the report done by Hunshui Institution reveals the huge problems and threats with its VIE structures, which leads to market panic selling and its stock price fell for $34 \%$ in a single day and another $35 \%$ fell in the following eight hours and the sharp fell of its reputation. The structural problems caused low efficiency and need to be adjusted little by little in a relatively long period of time.

\section{ADVANCEMENT FOR THE FUTURE}

\subsection{Change of advertisement methods}

New Oriental Education used to focus greatly on advertisements in public places, such as billboards, bus advertisement and pamphlets handed out on the side of the streets [5]. However, with the development and popularity of internet and short videos, New oriental education should spread more innovative advertisement on public online platforms. 
Taking TAL Education Group, another large education company, as an example, the teachers provide public classes on trending streaming platforms such as Bilibili and organizes lucky draws with studying materials from TAL Education Group, and posts videos with original songs about key points of learning subjects on Wechat short videos, which is an affiliated platform of the widely-used social software Wechat. All the platforms involved, all prizes and every click and repost are effective advertisement for the company, while New Oriental is losing such opportunity. The trial of other education companies on streaming and videos are also receiving success, and if possible, New Oriental Education should follow up the trend and quickly develop some attractive advertising methods online and gain back the attention of parents and students.

\subsection{Personalized Service}

New Oriental Education has already made efforts on personalization on its Study Abroad Express program, but it is inadequate as the company is still trying to serve most students according to generalized data analysis and simulation of previous successful cases. Shortly speaking, the work New Oriental Education done is still imitating and generalizing without unique project designs starting from the situations of individual employees.

For solutions, there are already several companies that successfully found their unique methods of personalization. Xueersi has developed ITS, a system which allows each student to see the results and answers of class questions and daily quizzes, and teachers could easily see these detailed and summarized results simultaneously to manage how much the students master the class content and contact students to offer help and support. Another abroad education company, New Oriental Education, has acquired each student a personal teaching assistant who manages the students' classes and can answer questions from their class contents to overall arrangements.

All these projects started from the characteristics of each student, and with economics of scale, New Oriental Education should invest on some teaching software which provides every individual their own status and allow teachers to deal with these circumstances and make adjustments. With many experienced teachers, it is possible for New Oriental Education to arranges several students to one teacher and design separate independent plans according to their learning abilities. For abroad preparations, specialized teachers are needed to make schedules for each student with various future majors and different dream schools. Although it may cause an increase in cost on salaries of teachers and cost of software development, these improvements on personalized service will complete the key turn of New
Oriental Education' s advancement and satisfy needs of more potential clients.

\section{CONCLUSION}

Above all, New Oriental Education has advantages in the competition in the education industry. For reputation, it has old brand influence and advertisements done by stars that effectively raise its popularity among different categories of people. One-package service and strategies on courses and prices explains the secret of its success in academic fields. Existing problems includes the negative influence of epidemic situation and inter-company competition, and an impending adjustment needed is the personalization of services. The predictions include changes on advertising methods that helps the company gain more popularity under the new environment of multimedia. Methods of designing individual plans are also analyzed by exampling succeeded cases and raising a possible solution in context of the company's programs.

Limitation of the paper includes less information from management groups. Instead, the paper mainly discusses from the perspective of customers and raise problems and solutions that aim to satisfy the consumers' need, which is an essential phase of marketing but not the whole story. What is more, suggestions are still based on successful cases and hypothesis, while mathematical models are not yet created to solidify the reliability of these solutions. The author will try to calculate more on math and economics in specific to test the hypotheses, and more importantly, will investigate on the supply side of the education industry.

\section{ACKNOWLEDGMENTS}

First and foremost, I would like to show my deepest gratitude to my teachers, who have provided me with valuable guidance in every stage of the writing of this thesis. Further, I would like to thank my friends and parents for their encouragement and support. Without all their enlightening instruction and impressive kindness, I could not have completed my thesis.

\section{REFERENCES}

[1] Data from formal website of New Oriental Education, online available, accessed on April 3rd, http://www.xdf.cn/

[2] Content paraphrased from the interview on the 16th China International Education Touring Exhibition, online available, accessed on April 3rd, https://edu.qq.com/a/20110408/000290.htm 
[3] Z. X. Ma, Analysis of New Oriental Education Group's Marketing Tactics[J]. National Business Situation (Theoretical Research), 2012(10): 29+33.

[4] Q. L. Deng, Observing short problems of New Oriental by Hunshui institutions by VIE models, [J]. Accountant, 2015(11): 18-19.

[5] H. B. Wang, New Oriental marketing ideas and actual combat, online available, accessed on April 3rd,

https://new.qq.com/omn/20190904/20190904A03A Y300.html

[6] Data from interview of the founder of New Oriental Education, reported on September 4th, 2019, online available, accessed on April 3rd, https://new.qq.com/omn/20190904/20190904A03A Y300.html 